\title{
Not Losing the EFL Plot: L2 Engagement through Literature (Reading Circles) and Producing Short Stories (Creative Writing Circles)
}

\author{
Kevin M Maher*
}

Faculty of Arts and Humanities, University of Macau, Macau

Corresponding Author: Kevin M Maher, E-mail: kmaher@umac.mo

\begin{tabular}{l} 
ARTICLE INFO \\
\hline Article history \\
Received: March 01, 2018 \\
Accepted: May 09, 2018 \\
Published: September 01, 2018 \\
Volume: 7 Issue: 5 \\
Advance access: July 2018 \\
\hline
\end{tabular}

Conflicts of interest: None

Funding: None

\begin{abstract}
Reading and writing stories (literature) can be an effective way to engage students' L2. Pedagogically, teachers are looking for ways to increase L2 input, and amplify L2 output. Because of the communicative nature of acquiring language, teachers are equally looking for collaboration among students to increase the usage of their L2 language. This paper proposes studying literature through Reading Circles and creating plot-focused short stories within a Writing Circles structure. It will theoretically establish the value of literature circles and creative writing circles in the EFL context, and share how language teachers can implement them.
\end{abstract}

Key words: EFL Writing Circles; Narrative Prose; Writing Collaboration; Peer Review; Literature Circles; Reading Circles; Narrative Writing; Creative Writing.

\section{THE CASE FOR LITERATURE CIRCLES AND WRITING CIRCLES WITHIN THE EFL CLASSROOM}

Literature and short story writing lead itself well to language acquisition when studying a foreign language. Hyland (2002) has been an active proponent of creative writing as a means of self-expression, which contributes to their L2. Bobkina and Dominguez (2014) examined how Literature has become more utilized in the EFL classroom and has discovered a role in EFL curriculum. Other researchers, such as Van (2009), showed how literature could involve a range of vocabulary, dialogues, and prose that help L2 learners acquire language. Hanauer (2001) shared how important it is to expose students to a canon of literary texts, and how this helps with understanding the culture of the target language. Elhess and Edbert (2015) shared how literature circles helped improve comprehension skills, participation, motivation, discussion, oral proficiency and how they reinforced writing skills. Dai (2011) shared how this could help students' writing, by allowing them a space to share their experiences, improve their writing ability, and increase their English language skills through creative writing. Ike and Nishi (2014) discussed the situation in Japan where creative writing reduced the anxiety of high-stakes traditional writing, which focused on grammar mistakes and accuracy. Another Japan research team, Kamata and Guenther (2014) discussed how creative writing not only helped develop English skills but also increased their confidence in the L2. Consistent with Hisatsune (2012), who stated that teachers by nature look for activities that increase students' confidence and skills so that students can become more autonomous and capable learn- ers. Maley (2012) described how creative writing feeds into students ability to read and analyze reading activities. More and more, both literature and creative writing have become tools to increase the L2 acquisition process of English learners throughout the EFL world.

\section{THE VALUE OF COLLABORATION FOR L2 STUDENTS}

Any discussion on the collaborative methods of teaching always begins with Vygotsky. The Zone of Proximal Development (ZPD) has been a cornerstone in the theory that what students might not understand themselves, they could confer with peers and teachers to get to the next level (Vygotsky, 1978). Applying it to both language acquisition and creative writing, ZPD implies that by discussing and working with peers, they can increase their awareness to improve those skills. Harmer (2007) described the concept of Communicative Language Teaching (CLT) which stresses meaningful communicative tasks, which increase language acquisition. Writing circles can lead to an enhancement of both writing skills and language skills, as students communicate in the target language. Lastly, VanPatten (2003) spoke about how interaction heightens learner's awareness and pushes them into being active in processing input. Just as relevant to acquiring language, it is essential to learn the skills of short story writing. We need feedback given by the teacher, from the peers, and from the material, that subsequently later improves output. Essentially, according to Kanamura, et al. (2013) when students learn in groups, they are exposed to more ideas than working alone. They increase both their input and output. 


\section{THE LITERATURE CIRCLE}

Prior to writing short stories, students need to learn some elements of the short story structure. Examining literature can be a model for their writing. As Kumata and Guenther (2014) state, creative writing within EFL, not only teaches the craft of writing but also exposes students to the literature of published authors.

According to Maher (2014), each literature circle member will have a role that they prepare beforehand. Rolework is the preparation of their task so that they arrive at the Circle ready to discuss with the group. In a literature circle, teachers assign the same text to all students. For any given circle, it is recommended that members are between four to five members. No more than five, but not less than four to be effective. Assessment is based on their contribution by both produced rolework (to be handed-in) and observed contribution as they discuss the literature.

The primary goal is to have students examine the literature beforehand and then discuss it within the class period itself. Typical writing circles will last 45 minutes to an hour, dependent on the type of discussion that students generate. The teacher can act as a facilitator, and assist students with anything that students propose as troublesome. Additionally, circles are student-paced and focus on each groups' interests, as opposed to the teacher's pace and interests (Maher 2013, Maher 2014, Maher 2015).Below (Table 1) are examples of Literature Circles roles:

\section{'SHORT STORY' WRITING ROLES}

Once students understand the concept of Literature Circles, it can be applied to their 'Short Story' Writing Circles. Below are recommended roles, but it is up to the teacher's discretion based on the focus of their assignments and teaching. Teachers without a Creative Writing background might want to examine other aspects of the writing craft for short story development. One recommendation would be Anderson and Neale (2009) who discuss in detail about character, plot, point-of-view, voice, setting, structure, and show and tell; within the creative writing context. Another suggestion would be the work of Kelen (2006), who focuses on the Story Circle and aspects such as conflict and resolution, identification and empathy, and credible and convincing.

Prior to examining each other's narrative writing, it is recommended that the teacher give one example from an established literary work, preferably from earlier assigned literature circle texts. Students can discuss the writing craft with the writing circle roles, re-examining the same text from a creative writing perspective. This is beneficial before attempting to produce their own short story.

Within the writing circle structure, students will read the work of their fellow peers within their respective writing circle. Each member will examine each members' short story but from the perspective of their role. Because creative writing has fewer strict requirements than academic writing, it is advisable to avoid a focus on spelling and grammar, unless they are instrumental in comprehending their written text. Equally, it is encouraging for students to focus on the story-telling craft as opposed to grammatical perfection. Short story and creative writing allow an opportunity to communicate through language, as opposed to a high-stakes focus on $100 \%$ accurate sentences.

Below are listed seven roles. These are only as examples, but for an effective writing circle, a group of 4-5 is ideal, so a teacher should only have the students be assigned 4-5 of these roles, one role per member. Below are suggested for Short Story Writing Circle roles (Table 2):

\section{CONCLUSION}

In conclusion, reading and writing circles can be effective in the language classroom to enhance L2 literacy and expose

Table 1. Literature circle roles

\begin{tabular}{ll}
\hline Discussion leader & $\begin{array}{l}\text { This person's role is to lead the discussion. They need to write up to } 10 \text { discussion questions for the group. } \\
\text { The questions must be designed to encourage discussion. Anything related to the story that helps examine } \\
\text { and reflect on the story is preferred. }\end{array}$ \\
This role examines problematic or critical passages within the chosen text, to discuss further. These passages \\
may include the linguistically challenging for EFL students to understand. \\
Graphic organizer & $\begin{array}{l}\text { This role is for the artistically talented of the group. Another organizational style would be to print off } \\
\text { pictures from the internet, which have a visual component to them. The goal is to draw arrows and/or utilize } \\
\text { timelines, to share the plot and key scenes with the other members in a visual manner. }\end{array}$ \\
Vocabulary \& & $\begin{array}{l}\text { This role examines the problematic idioms and vocabulary that are difficult for the EFL student to } \\
\text { idiom wizard } \\
\text { comprehend. This person will be in charge of all unknown words, and to test the group later on their } \\
\text { meaning, or to discuss them contextually within their respective passages. They may use photos from the } \\
\text { internet, to help visually see the word or idiom. It is recommended that as this role is regarded as an 'easier' } \\
\text { one, this person should equally develop a short quiz to distribute, to challenge the students' acquisition of } \\
\text { listed keywords. } \\
\text { A more challenging role, this person will generate discussion based on elements of the story that might } \\
\text { inspire connections with student's real lives. For example, if there is an element of the story where } \\
\text { characters interact with a police officer, this role may examine the interaction others' have had with police } \\
\text { officers. They will be required to create as many connections as possible so that students can consider how } \\
\text { they might respond to similar situations within the literature. It is a way that students can reflect on the text, } \\
\text { and how it might relate to their own lives, and examine cultural differences. }\end{array}$ \\
\end{tabular}


Table 2. Short story writing roles

\begin{tabular}{|c|c|}
\hline "Hook" impact person & $\begin{array}{l}\text { How compelling is the story at hooking us within the first few paragraphs? Equally, does } \\
\text { it foreshadow later events? This role will examine all hooks, and describe which ones had } \\
\text { the most impact as a reader, and why. }\end{array}$ \\
\hline "Plot" examiner & $\begin{array}{l}\text { This person will examine the plot and its effectiveness. If it doesn't work, how could it } \\
\text { be developed more? If it does work, what characteristics make it effective? This role will } \\
\text { want to write out a plot curve and place events into a timeline. The traditional plot curve } \\
\text { examines character introduction, initial conflict, escalation, climax and resolve. }\end{array}$ \\
\hline "Character development" demonstrator & $\begin{array}{l}\text { This role examines the characters (a maximum of three in a short story is the } \\
\text { recommended limit). How they are introduced into scenes, how they are developed, and } \\
\text { how they are shown to have relationships with other characters in the piece. This role will } \\
\text { examine which stories/authors developed the more interesting characters and why they } \\
\text { were interesting. }\end{array}$ \\
\hline "Location and scene" seer & $\begin{array}{l}\text { This role will search for all aspects of scene and location and within the stories. How does } \\
\text { the author describe the scene? What kind of events can take place because of the area? } \\
\text { How does the author show it? What other aspects did the author miss, that might have } \\
\text { been interesting to display based on location? Upon examining all papers, this role will } \\
\text { say which scenes were most vivid, most memorable. }\end{array}$ \\
\hline "Dialogue" demon & $\begin{array}{l}\text { This person will examine all aspects of dialogue. How it was used, and what were } \\
\text { characters doing during dialogue (if anything). Is the dialogue natural or does it feel } \\
\text { unnatural? What are the statement verbs that the author chooses for dialogue? This role } \\
\text { will examine which authors were most effective in having good dialogue, and what } \\
\text { elements made them better. }\end{array}$ \\
\hline "Show don't tell" shower \& teller & $\begin{array}{l}\text { A more advanced role. This person will search the texts to give examples of when the } \\
\text { author chose to show a scene, versus tell a scene. Equally, this role will share how a 'told' } \\
\text { scene could instead be 'shown.' Upon examining their peers' writing, which writer (s) } \\
\text { were most effective in showing scenes? }\end{array}$ \\
\hline "Metaphor \& symbolism" mystic & $\begin{array}{l}\text { Another advanced role. This person will attempt to pinpoint anything in the story } \\
\text { that might relate to these two aspects of a story. This might be difficult for the second } \\
\text { language learner, but may be an appealing and challenging role for any student with a } \\
\text { strong literature background. }\end{array}$ \\
\hline
\end{tabular}

students to a low-stakes creative playfulness of the language, as opposed to high-stakes grammatical accuracy. The collaborative nature of rolework allows the students to scaffold what they don't know, into what they collectively learn with their peers. Additionally, because students are studying the written form of English in their respective literature and creative writing circles, this gives students an opportunity to interact with the text, examine it, discuss it, work out the meaning, and discuss the words, in a meaningful and purposeful way. All in all, studying literature through reading and writing circles, can be an effective and creative teaching strategy to increase both student input and student output in their L2.

\section{REFERENCES}

Anderson, L. \& Neale, D. (2013). Writing Fiction, Routledge: New York.

Bobkina, J. \& Dominguez, E. (2014). The use of literature and literary texts in the EFL Classroom; between consensus and controversy. International Journal of Applied Linguistics \& English Literature 3(2), doi:10.7575/aiac. ijalel.v.3n.2p.248.

Dai, F. (2011). Writing, Sharing and Growing: Creative Writing in English at a Mainland Chinse University. In Camens \& Wilson (Eds.), TEXT Special Issue: Creative
Writing in the Asia-Pacific Region. Australia: TEXT Journal.

Elhess, M. \& Egbert, J. (2015). Literature circles as support for language development. English Teaching Forum 53(3), pps 13-22.

Hamer, J. (2007). The practice of English language teaching. London: Pearson.

Hanauer, D. (2001). Focus-on-cultural understanding: Literary reading in the second language classroom. CAUCE, Revista de Filología y su Didáctica 24, pps 394-404.

Hisatsune, A. (2012). Enhancing learner autonomy through reading circles. In A. Stewart \& N. Sonda (Eds.), JALT2011 Proceedings. Tokyo: JALT.

Hyland, K. (2002). Teaching and researching writing. London: Longman.

Ike, S., \& Nishi, M. (2014). Creative writing in ELT: Extremely short stories. In N. Sonda \& A. Krause (Eds.), JALT2013 Conference Proceedings. Tokyo: JALT.

Kamata, S., \& Guenther, D. (2014). Fundamentals of creative writing for Japanese university students. In $\mathrm{N}$. Sonda \& A. Krause (Eds.), JALT2013 Conference Proceedings. Tokyo: JALT.

Kanamura, A., Laurier, J., Plaz, T., \& Shiramizu, C. (2013). Cooperative learning as a facilitator to communicative EFL teaching. In N. Sonda \& A. Krause (Eds.), JALT2012 Conference Proceedings. Tokyo: JALT. 
Kelen, K. (2006). The Story Circle Manual. Macau: ASM Association of Stories in Macau.

Kelen, K. (2014). Process and product, means and ends: Creative Writing in Macau. In D. Disney (Ed.), Exploring Second Language Creative Writing: Beyond Babel. Philadelphia/Amsterdam: John Benjamins Publishing Company.

Maher, K. (2013). Literature Circles: Acquiring language through collaboration. In S. Miles \& M. Brierly (Eds.), Extensive Reading World Congress Proceedings, 2013, 36-45. Seoul: Extensive Reading Foundation.

Maher, K. (2014). Literature Circles: Collaboration and community. In R. Chartrand, G. Brooks, M. Porter \& M. Grogan (Eds.), The 2013 PanSIG Conference Proceedings, 227-234. Nagoya, Japan: JALT. http://www. pansig.org/2013/2013PanSIGProceedings.pdf

Maher, K. (2015). EFL Literature Circles: Implementation and Assessment. In D. Shaffer, M. Pinto (Eds.), KOTESOL 2014 Conference Proceedings. Seoul:
KOTESOL, pps. 115-123. https://koreatesol.org/sites/ default/files/pdf_publications/KOTESOL.Proceedings.2014.web_.pdf

Maley, A. (2012). Creative writing for students and teachers. Humanizing Language Teaching Magazine 14(3). http:// www.hltmag.co.uk/jun12/mart01.htm

McKay, S. (1986). Literature in the ESL Classroom. In C. Brumfit \& R. Cárter (eds.), Literature and Language Teaching. Oxford: Oxford University Press, pps 191-198.

Van, T. (2009). The relevance of literary analysis to teaching literature in the EFL Classroom. English Teaching Forum 47(3), pps 2-9.

VanPatten, B. (2003). From input to output: A teacher's guide to second language acquisition. Chicago: McGraw-Hill.

Vygotsky, L. (1978). Mind in Society: The development of higher psychological processes. Cambridge, MA: Harvard University Press. 